\title{
Complete genome analysis of a frog virus 3 (FV3) isolate and sequence comparison with isolates of differing levels of virulence
}

\author{
Elizabeth A Morrison ${ }^{1}$, Shawn Garner ${ }^{1,2 \dagger}$, Pierre Echaubard ${ }^{3 \dagger}$, David Lesbarrères ${ }^{2}$, Christopher J Kyle \\ and Craig R Brunetti ${ }^{1^{*}}$
}

\begin{abstract}
Background: Frog virus 3 (FV3) is the type species of the genus Ranavirus, and in the past few decades, FV3 infections have resulted in considerable morbidity and mortality in a range of wild and cultivated amphibian species in the Americas, Europe, and Asia. The reasons for the pathogenicity of FV3 are not well understood.

Findings: We investigated three FV3 isolates designated SSME, wt-FV3, and aza- $C^{r}$, and reported that our wt-FV3 and aza- $C^{r}$ strains showed similar levels of virulence, while SSME was the least virulent in an in vivo study with Lithiobates pipiens tadpoles. Using 454 GS-FLX sequencing technology, we sequenced SSME and compared it to the published wt-FV3 genome. SSME had multiple amino acid deletions in ORFs 49/50L, 65L, 66L, and 87L, which may explain its reduced virulence. We also investigated repeat regions and found that repeat copy number differed between isolates, with only one group of 3 isolates and 1 pair of isolates being identical at all 3 locations.

Conclusions: In this study we have shown that genetic variability is present between closely related FV3 isolates, both in terms of deletions/insertions, and even more so at select repeat locations. These genomic areas with deletions/insertions may represent regions that affect virulence, and therefore require investigation. Furthermore, we have identified repeat regions that may prove useful in future phylogeographical tracking and identification of ranaviral strains across different environmental regions.
\end{abstract}

Keywords: FV3, 454 GS-FLX technology, Viral isolates, Genetic variation, Virulence

\section{Background}

Global amphibian populations have declined considerably in recent years, in part due to habitat fragmentation, pollution, and the chytrid fungus Batrachochytrium dendrobatidis [1,2]. More recently, certain members of the family Iridoviridae have also been associated with amphibian decline. The family Iridoviridae is comprised of large, cytoplasmic, double stranded DNA viruses with icosahedral capsids [3], and is divided into five genera: Iridovirus, Chloriridovirus, Lymphocystivirus, Megalocytivirus, and Ranavirus [4]. Specifically linked to amphibian mortality in this family are infectious diseases caused by members of the genus Ranavirus. In past research,

\footnotetext{
* Correspondence: craigbrunetti@trentu.ca

${ }^{\dagger}$ Equal contributors

'Department of Biology, Trent University, 1600 East Bank Dr., Peterborough, Ontario K9J 7B8, Canada

Full list of author information is available at the end of the article
}

ranaviruses received little attention as most infections were deemed subclinical; however, recent ranavirus infections have resulted in considerable morbidity and mortality in a range of wild and cultivated amphibian species in the Americas, Europe, and Asia [5-8]. It has been reported that $43 \%$ of known amphibian die-offs in the USA from 2000 to 2005 were due to ranaviruses [9], and that from 1996-2001 ranaviruses were isolated from most of the amphibian mortality events in North America [10]. Detection of these outbreaks could be due to better surveillance, increased environmental awareness, the mutation of viral species creating highly pathogenic strains, or environmental changes resulting in host immune suppression [11]. Ranaviruses have become a significant cause of death and disease in amphibians, and thus investigation into these viruses is warranted from a virological, commercial, and ecological standpoint [11]. 
Frog virus 3 (FV3) is the type species of the genus Ranavirus [4]. FV3's genome is 105,903 base pairs (bp) comprised of 98 open reading frames (ORFs) [12]. Depending on factors such as strain virulence and host immune response, infection with FV3 may or may not lead to mortality. However, in susceptible amphibians, FV3's necrotic and apoptotic effects cause systemic, chronic cell death in multiple internal organs, resulting in death of the host within a few days to several weeks $[2,13,14]$. FV3 infection is also marked by cutaneous signs, including ulceration of the skin, and erythema and swelling of the limbs and body. In fatal cases, intracoelomic lesions are often present, including haemorrhages of the kidneys and reproductive organs, and pale, swollen livers [15]. While our understanding of ranavirus pathogenicity has improved over the last decade, there is still a need for the research community to more fully describe the determinants of virulence variation. Elucidation of this area will likely heavily rely on the genetic analysis and comparison of ranaviruses that differ in host range and virulence.

Genetic comparison of related DNA viruses has proven to be an important tool in classifying viral strains and understanding the epidemiology and evolution of different genotypes [16]. By analyzing genetic differences, researchers can link clinically significant alterations with molecular changes, and better understand viral origins and evolution. Increasingly, new viral strains are being identified based on the systematic analysis of sequence data, including short amino acid insertions, translational stop codons, and single amino acid deletions [17]. Analysis of viral isolates has led to the discovery of new viral genotypes, as well as better understanding of the functional genetic differences among strains [17]. For instance, the entire genome of a virulent strain of duck entiritis virus was recently sequenced and compared to the genomes of an attenuated strain and another virulent strain [18]. The results indicated several nucleotide insertions/deletions and frame-shift mutations effecting ORF initiation or termination [18]. These findings allowed the researchers to identify possible virulence factors and provided information on ORFs that are changed during serial passage.

In addition to nucleotide insertions/deletions, variation between viral genomes may occur at repeat regions. Eaton et al. [19] identified repetitive sequences in the genomes of various ranaviruses with high copy number variation. Repetitive sequences are commonly classified into one of three groups: macro, mini, or micro satellites [20]. The repeats that we will examine in this study contain less than 400 bp comprised of 9-19 bp repeating units. Thus, we suggest that these repeats are some variation between micro and mini satellites, and for the purposes of our analysis, will be referred to as short tandem repeats (STRs). A selection of these repeat regions will be used to analyze FV3 isolates in order to further investigate the fine scale, genetic differences present in variable regions.

Past studies on the genetic variation between DNA viral strains have allowed for the detection of minute genetic changes that would otherwise have gone unnoticed. These kinds of changes have proved useful in explaining phenotypic differences and evolutionary histories. The purpose of the present investigation is to narrow our focus even further by comparing the genomes of closely related FV3 isolates, including those with varying levels of virulence. This will be done in an attempt to explore the genetic diversity present in strains of FV3, with the ultimate goal of further elucidating the possible genetic basis behind FV3's unpredictable infectious behaviour.

\section{Results}

FV3 strains differ in virulence during in vivo infection

In order to determine if FV3 strains SSME, wt-FV3, and aza- $\mathrm{C}^{\mathrm{r}}$ induced different degrees of infection, $L$. pipiens tadpoles were exposed to each strain. Tadpoles were exposed to FV3-infected water for $12 \mathrm{~h}$ before being transferred to FV3-free water for the remainder of the experiment. The tadpoles were monitored for 41 days, at which time all tadpoles had either died or reached metamorphosis. The results of the survival analysis revealed significant differences in strain effect on tadpole mortality rates $\left(X^{2}=21.3, p<0.01\right)$. Although deaths triggered by wt-FV3, aza-C ${ }^{\mathrm{r}}$, and SSME stocks peaked between 15 and 18 days post infection, overall mortality was higher following infection with wt-FV3 and aza- $\mathrm{C}^{\mathrm{r}}$ virus $(>96 \%)$ than with SSME (84\%). Wt-FV3 induced a mortality of $97 \%$, and aza- $\mathrm{C}^{\mathrm{r}}$ a mortality rate of $96 \%$ (Figure 1 ). In contrast, SSME infected tadpoles reached a mortality plateau after 28 days, and showed a mortality rate of $84 \%$. The control tadpoles had the lowest mortality, with a rate of $66 \%$ after 41 days (Figure 1). These data demonstrate that the closely related FV3 strains, wt-FV3 and aza- $\mathrm{C}^{\mathrm{r}}[21,22]$, are associated with higher mortality than SSME (Figure 1). Of concern was the high mortality seen even in control tadpoles (Figure 1). We did confirm that the control tadpoles, both those that survived and those that died, were ranavirus negative (data not shown). This mortality could be the result of overcrowding of tadpoles during infection. In addition, this mortality is occurring during the first few days of the experiment at a time when the tadpoles are very small and very weak, very sensitive to stressful conditions. At the beginning of the experiment, the tadpoles are transferred from tank to tank that may account for the high mortality rate early on in the experiment or may have resulted in high mortality of a sublethal viral dose. 


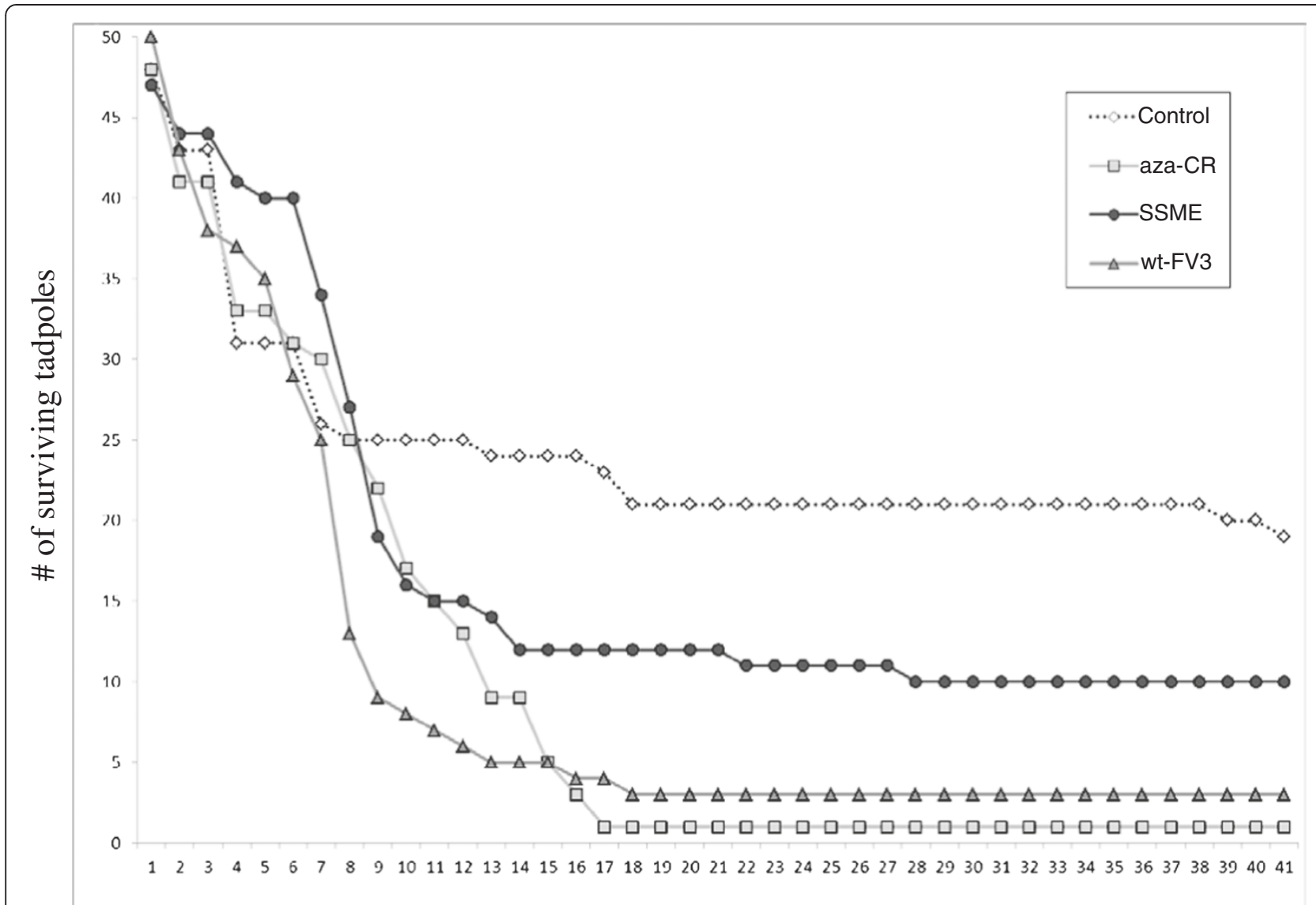

\section{Days of Infection}

Figure 1 Variable virulence of three FV3 strains during tadpole infection. Survival analysis of L. pipiens tadpoles over 41 days of infection with aza-C' (square), SSME (circle), wt-FV3 (triangle), and Control (diamond). Tadpoles were exposed to FV3 strains for 12 hours, and then along with the virus-contaminated water were transferred to a tank of dechlorinated water for the remainder of the experiment. Survival analysis and failure time analysis was done following the Kaplan \& Meier product limit method associated with Chi square and Gehan's Wilcoxon tests [37].

\section{Genomic sequencing of SSME}

In order to better understand the possible genetic basis of phenotypic variation among strains, we sequenced the SSME strain using 454 GS-FLX technology. Our sequenced genome showed high similarity to the published FV3 sequence (wt-FV3) [12], with a sequence identity of 98.79\% and average genome sequencing coverage of 51x. Results revealed that SSME differed from the wt-FV3 genome length of 105,903 bps and ORF number of 98; instead, SSME had a length of $105,070 \mathrm{bps}$, and a total of 95 predicted ORFs (Table 1). Despite high overall sequence identity between SSME and FV3, marked differences were noted in several regions of the genome (Table 2).

\section{Gene variation between ranaviruses}

In order to investigate the possible genetic variation within coding regions and regions of high variability between closely related viral isolates, we compared our sequenced SSME genome with four published ranavirus genomes. The genomes compared included: SSME, wtFV3 [17], rana grylio iridovirus (RGV) [23], soft-shelled turtle iridovirus (SSTIV) [24], and tiger frog virus (TFV) [25]. We began by focusing our analysis on predicted coding regions, as variation in these areas may have consequences in pathogenicity or the kind of disease a virus causes.

Upon analysis of selected ranaviral genomes, a $757 \mathrm{bp}$ deletion was discovered in SSME, deleting the entire 65L coding region and the majority of the $66 \mathrm{~L}$ coding region (Figure 2). This deletion was not present in wt-FV3 or in related ranaviruses RGV, SSTIV, and TFV. However, sequence alignments indicated reorganization of $66 \mathrm{~L}$ in RGV, SSTIV, and TFV, with a 139 bp insertion found in their corresponding 66L regions (Figure 2). Therefore, there are at least 3 different genomic presentations of this region in ranaviral genomes, making it highly variable among isolates.

Another coding region demonstrating variation was 50L. An in frame deletion of 13 amino acids was found 
Table 1 Description of nucleotide start/stop locations and amino acid length of ORFs in SSME, along with predicted functions

\begin{tabular}{|c|c|c|}
\hline \multirow[b]{2}{*}{ ORF } & \multirow{2}{*}{$\begin{array}{l}\text { Start/stop (\#aa) } \\
\text { SSME }\end{array}$} & \multirow[b]{2}{*}{ Predicted function/conserved domains } \\
\hline & & \\
\hline \multirow[t]{2}{*}{$1 \mathrm{R}$} & $272-1042$ & \multirow[t]{2}{*}{ Replication factor \&/or DNA packing protein } \\
\hline & 255aa & \\
\hline \multirow[t]{2}{*}{$2 \mathrm{~L}$} & $1649-2629$ & \multirow{2}{*}{$\begin{array}{l}\text { Myristylated membrane protein, } \\
\text { DUF230 poxvirus protein, TM* }\end{array}$} \\
\hline & 325aа & \\
\hline \multirow[t]{2}{*}{$3 R$} & $3436-4752$ & \multirow[t]{2}{*}{ IIV6 ORF 229L, SP } \\
\hline & 437aa & \\
\hline \multirow[t]{2}{*}{$4 \mathrm{R}$} & $4793-4975$ & \multirow[t]{2}{*}{ TM } \\
\hline & $59 a a$ & \\
\hline \multirow[t]{2}{*}{$5 R$} & $5408-6022$ & \multirow{2}{*}{$\begin{array}{l}\text { FPV ORF } 250 \text {, US22, herpes virus early } \\
\text { nuclear protein }\end{array}$} \\
\hline & 203aа & \\
\hline \multirow[t]{2}{*}{$6 \mathrm{R}$} & $6025-6252$ & \multirow[t]{2}{*}{$\mathrm{SP}^{*}$} \\
\hline & $74 a a$ & \\
\hline \multirow[t]{2}{*}{$7 \mathrm{R}$} & 7043-7429 & \multirow[t]{2}{*}{ SP } \\
\hline & 127aa & \\
\hline \multirow[t]{2}{*}{$8 \mathrm{R}$} & $7521-11402$ & \multirow{2}{*}{$\begin{array}{l}\text { DNA-dependent RNA polymerase largest } \\
\text { subunit }\end{array}$} \\
\hline & 1292aа & \\
\hline \multirow[t]{2}{*}{$9 L$} & $11771-14617$ & \multirow{2}{*}{$\begin{array}{l}\text { NTPase, SNF2 family, N-terminal, } \\
\text { helicases C-terminal, DEAD/H helicases }\end{array}$} \\
\hline & 947aa & \\
\hline \multirow[t]{2}{*}{$10 R$} & 14633-15046 & \multirow[t]{2}{*}{ TM } \\
\hline & 136аa & \\
\hline \multirow[t]{2}{*}{$11 \mathrm{R}$} & 15396-15608 & \multirow[t]{2}{*}{ TM } \\
\hline & 69aа & \\
\hline \multirow[t]{2}{*}{$12 \mathrm{~L}$} & $15674-16567$ & Unknown protein, SP \\
\hline & 296aа & \\
\hline $13 R$ & $17108-17314$ & SP \\
\hline & $67 a a$ & \\
\hline $14 \mathrm{R}$ & 17329-17688 & Unknown protein, SP \\
\hline & 118aa & \\
\hline $15 R$ & $17784-18752$ & AAA-ATPase, poxvirus A32 \\
\hline & 321 aа & \\
\hline $16 \mathrm{R}$ & 19032-19859 & Integrase homologue \\
\hline & 274aa & \\
\hline 17L & $20100-21608$ & SP \\
\hline & $501 a a$ & \\
\hline $18 \mathrm{~L}$ & $21645-21881$ & TM \\
\hline & $77 a a$ & \\
\hline $19 R$ & 21933-24515 & Similar to LCDV1 or f10L conserved \\
\hline & 859aa & \\
\hline $20 \mathrm{R}$ & $24562-25008$ & Unknown protein, TM \\
\hline & 147aa & \\
\hline $21 L$ & $25231-25890$ & ISKNV ORF 56L-like protein \\
\hline & 218aa & \\
\hline
\end{tabular}

Table 1 Description of nucleotide start/stop locations and amino acid length of ORFs in SSME, along with predicted functions (Continued)

\begin{tabular}{|c|c|c|}
\hline \multirow[t]{2}{*}{$22 \mathrm{R}$} & $26020-28941$ & \multirow[t]{2}{*}{ D5 family NTPase, ATPase } \\
\hline & 972aа & \\
\hline \multirow[t]{2}{*}{$23 R$} & 29319-30467 & \multirow[t]{2}{*}{ SP } \\
\hline & 381 aа & \\
\hline \multirow[t]{2}{*}{$24 R^{\circ}$} & 30877-31947 & \multirow[t]{2}{*}{ SP } \\
\hline & 355aa & \\
\hline \multirow[t]{2}{*}{$25 R$} & $32141-32929$ & \multirow[t]{2}{*}{ P31K protein } \\
\hline & 261 aa & \\
\hline \multirow[t]{2}{*}{$26 \mathrm{R}$} & 32996-33226 & \multirow[t]{2}{*}{ Truncated elf-2a homologue } \\
\hline & $75 \mathrm{aa}$ & \\
\hline \multirow[t]{2}{*}{$27 \mathrm{R}$} & $33757-36669$ & \multirow{2}{*}{$\begin{array}{l}\text { Tyrosine kinase, CAP 10, putative } \\
\text { lypopolysaccharide modifying enzyme }\end{array}$} \\
\hline & 969aа & \\
\hline \multirow[t]{2}{*}{$28 \mathrm{R}$} & 36718-37206 & \multirow[t]{2}{*}{ Unknown protein, SP } \\
\hline & 161 aa & \\
\hline \multirow[t]{2}{*}{$29 \mathrm{~L}$} & $37385-37681$ & \multirow[t]{2}{*}{ SP } \\
\hline & $97 a a$ & \\
\hline \multirow[t]{2}{*}{$30 R$} & 37883-38035 & \multirow[t]{2}{*}{ TM } \\
\hline & 49aа & \\
\hline \multirow[t]{2}{*}{$31 R$} & 38097-38516 & \multirow[t]{2}{*}{ SP } \\
\hline & 138aa & \\
\hline \multirow[t]{2}{*}{$32 R$} & $38566-40458$ & \multirow[t]{2}{*}{ Neurofilament triplet $\mathrm{H} 1$ protein } \\
\hline & 629aa & \\
\hline \multirow[t]{2}{*}{$33 R$} & 40541-40732 & \multirow[t]{2}{*}{ Unknown protein, TM } \\
\hline & 62aa & \\
\hline \multirow[t]{2}{*}{$34 R$} & 40875-41195 & \multirow[t]{2}{*}{ Human parainfluenza virus $1 \mathrm{~L}$ like protein, TM } \\
\hline & 105aa & \\
\hline \multirow[t]{2}{*}{$35 \mathrm{~L}$} & $41287-41748$ & SP \\
\hline & 152aa & \\
\hline $36 \mathrm{~L}$ & $41761-42384$ & SP \\
\hline & 206aа & \\
\hline $37 R$ & $42778-43413$ & NIF/NLI interacting factor \\
\hline & 210aa & \\
\hline $38 \mathrm{R}$ & $43554-45251$ & Ribonucleoside diphosphate reductase \\
\hline & $564 a a$ & alpna subunit Darrel domain \\
\hline $39 R$ & $45357-45707$ & Hydrolase of the metallo-beta-lactamase \\
\hline & 115aa & superfamily \\
\hline $40 R$ & $45795-46343$ & TM \\
\hline & $181 \mathrm{aa}$ & \\
\hline $41 R$ & $46725-50222$ & RRV ORF-2-like protein, SP \\
\hline & 1164aа & \\
\hline $42 \mathrm{~L}$ & 50718-50975 & SP \\
\hline & 84aa & \\
\hline
\end{tabular}


Table 1 Description of nucleotide start/stop locations and amino acid length of ORFs in SSME, along with predicted functions (Continued)

\begin{tabular}{|c|c|c|}
\hline \multirow[t]{2}{*}{$43 R$} & 50974-51491 & \multirow[t]{2}{*}{ TM } \\
\hline & 171aа & \\
\hline \multirow[t]{2}{*}{$44 \mathrm{R}$} & $51512-51697$ & \multirow[t]{2}{*}{ SP } \\
\hline & 60aa & \\
\hline \multirow[t]{2}{*}{$45 \mathrm{~L}$} & 51973-52383 & \multirow[t]{2}{*}{ LCDV1 ORF-88-like protein, SP } \\
\hline & 135aa & \\
\hline \multirow[t]{2}{*}{$46 \mathrm{~L} \S$} & $52437-53000$ & \multirow{2}{*}{$\begin{array}{l}\text { RGI 47L-like protein, SSTIV 049L-like } \\
\text { protein, Neurofilament triplet H1-like } \\
\text { protein, microneme/rhoptry antigen }\end{array}$} \\
\hline & 186aа & \\
\hline \multirow[t]{2}{*}{$47 \mathrm{~L}$} & $53125-53541$ & \multirow[t]{2}{*}{ SP } \\
\hline & 137aa & \\
\hline \multirow[t]{2}{*}{$48 \mathrm{~L}$} & $53544-53795$ & \multirow[t]{2}{*}{ SP } \\
\hline & $82 \mathrm{aa}$ & \\
\hline \multirow[t]{2}{*}{ 49/50Lף } & $53904-55451$ & \multirow{2}{*}{$\begin{array}{l}\text { LCDV1 ORF 58-like protein, RGI ORF } \\
\text { 50L-like protein, SSTIV ORF 052-like } \\
\text { protein, SAP DNA binding domain }\end{array}$} \\
\hline & 514aa & \\
\hline \multirow[t]{2}{*}{$51 R$} & $55531-57216$ & \multirow[t]{2}{*}{ Unknown, SP } \\
\hline & $560 a a$ & \\
\hline \multirow[t]{2}{*}{$52 \mathrm{~L}$} & $57473-58540$ & \multirow{2}{*}{$\begin{array}{l}\text { 3-beta-hydroxy-delta 5-C27 steroid } \\
\text { oxidoreductase-like protein, TM }\end{array}$} \\
\hline & 354aa & \\
\hline \multirow[t]{2}{*}{$53 R$} & $58878-60446$ & \multirow[t]{2}{*}{ LCDV1 ORF-20-like protein, SP } \\
\hline & 521 aa & \\
\hline \multirow[t]{2}{*}{$54 \mathrm{~L}$} & 60677-60907 & \multirow[t]{2}{*}{ Nuclear calmodulin-binding protein } \\
\hline & $75 a а$ & \\
\hline \multirow[t]{2}{*}{$55 \mathrm{~L}$} & $60945-62240$ & \multirow[t]{2}{*}{ Helicase-like protein } \\
\hline & 430aa & \\
\hline \multirow[t]{2}{*}{$55 R$} & $61089-62228$ & \multirow[t]{2}{*}{ FV3 40-kDa protein, SP } \\
\hline & 378aa & \\
\hline \multirow[t]{2}{*}{$56 \mathrm{R}$} & $62328-62765$ & SP \\
\hline & 144aa & \\
\hline $57 \mathrm{R}$ & $62879-64375$ & Phosphotransferase, S-TKc, Serine/ \\
\hline & 497aa & Threonıne proteın kınase \\
\hline $58 \mathrm{R}$ & $64700-65413$ & SP \\
\hline & 236аa & \\
\hline $59 L$ & 65964-67022 & RGV 9807 unknown protein, SP \\
\hline & 351 aа & \\
\hline $60 R$ & $67184-70225$ & DNA polymerase-like protein, DNA \\
\hline & 1012aа & polymerase family B exonuclease \\
\hline $61 \mathrm{~L}$ & 70234-70416 & SP \\
\hline & 59 aа & \\
\hline $62 \mathrm{~L}$ & $70859-74524$ & DNA-directed RNA polymerase II second \\
\hline & 1220aa & $\begin{array}{l}\text { largest subunit RNA polymerase domain } \\
6,7,3,2 \text { beta subunit }\end{array}$ \\
\hline $63 R$ & 74903-75397 & dUTPase-like protein \\
\hline & 163aа & \\
\hline
\end{tabular}

Table 1 Description of nucleotide start/stop locations and amino acid length of ORFs in SSME, along with predicted functions (Continued)

\begin{tabular}{|c|c|c|}
\hline \multirow[t]{2}{*}{$64 R$} & $75522-75809$ & \multirow{2}{*}{$\begin{array}{l}\text { Interleukin-1 beta convertase precursor, } \\
\text { Caspase-recruitment domain/DEATH }\end{array}$} \\
\hline & 94aa & \\
\hline $65 \mathrm{~L}^{\#}$ & N/A & SP \\
\hline \multirow[t]{2}{*}{$66 L^{\#}$} & $76106-76157$ & SP \\
\hline & $16 \mathrm{aa}$ & \\
\hline \multirow[t]{2}{*}{$67 \mathrm{~L}$} & $76212-77375$ & \multirow{2}{*}{$\begin{array}{l}\text { Ribonucleoside-reductase diphosphate } \\
\text { beta subunit-like protein }\end{array}$} \\
\hline & 386aa & \\
\hline \multirow[t]{2}{*}{$68 \mathrm{R}$} & 77657-77944 & SP \\
\hline & $94 a a$ & \\
\hline \multirow[t]{2}{*}{$69 R$} & $78080-78346$ & Unknown protein, TM \\
\hline & 87aa & \\
\hline \multirow[t]{2}{*}{$70 R$} & $78364-78738$ & SP \\
\hline & 123aа & \\
\hline \multirow[t]{2}{*}{$71 \mathrm{R}$} & $78778-79011$ & SP \\
\hline & 76 aа & \\
\hline \multirow[t]{2}{*}{$72 \mathrm{~L}$} & 79068-79784 & SP \\
\hline & 238aa & \\
\hline \multirow[t]{2}{*}{$73 \mathrm{~L}$} & $80232-81206$ & NTPase/helicase-like protein \\
\hline & 323aа & \\
\hline \multirow[t]{2}{*}{$74 \mathrm{~L}$} & $81381-82493$ & SP \\
\hline & 369aa & \\
\hline \multirow[t]{2}{*}{$75 \mathrm{~L}$} & $82525-82779$ & LITAF/PIG7 possible membrane associated \\
\hline & 83aа & $\begin{array}{l}\text { motif in LPS-Induced tumor necrosis factor } \\
\text { alpha factor, TM }\end{array}$ \\
\hline \multirow[t]{2}{*}{$76 \mathrm{R}$} & $82842-83063$ & SP \\
\hline & $72 \mathrm{aa}$ & \\
\hline \multirow[t]{2}{*}{$77 \mathrm{~L}$} & $83060-83407$ & LCDV ORF 2-like protein, SP \\
\hline & 114aa & \\
\hline \multirow[t]{2}{*}{$78 \mathrm{~L}$} & $84007-84645$ & SP \\
\hline & 211 aа & \\
\hline \multirow[t]{2}{*}{$79 R$} & 84781-86499 & ATPase-dependent protease \\
\hline & 571aa & \\
\hline \multirow[t]{2}{*}{$80 \mathrm{~L}$} & $87122-88237$ & Ribonuclease III-like protein \\
\hline & 370aa & \\
\hline \multirow[t]{2}{*}{$81 R$} & $88293-88571$ & Transcription elongation Factor SII, \\
\hline & 91 aа & C2C2 zinc finger \\
\hline \multirow[t]{2}{*}{$82 \mathrm{R}$} & $88700-89173$ & Immediate-early protein ICP-18 \\
\hline & 156aа & \\
\hline \multirow[t]{2}{*}{$83 R$} & $89623-90267$ & Cytosine DNA methyl-transferase \\
\hline & 213aа & \\
\hline \multirow[t]{2}{*}{$84 \mathrm{R}$} & $90652-91389$ & LCDV 1-like proliferating cell nuclear \\
\hline & 244aa & antigen, SP \\
\hline \multirow[t]{2}{*}{$85 R$} & $91464-92051$ & Deoxynucleoside kinase \\
\hline & 194aa & \\
\hline
\end{tabular}




\section{Table 1 Description of nucleotide start/stop locations and amino acid length of ORFs in SSME, along with predicted functions (Continued)}

\begin{tabular}{|c|c|c|}
\hline \multirow[t]{2}{*}{$86 \mathrm{~L}$} & $92441-92626$ & SP \\
\hline & 60aa & \\
\hline \multirow[t]{2}{*}{$87 L^{* *}$} & 92979-94778 & Unknown protein, SP \\
\hline & 598aa & \\
\hline \multirow[t]{2}{*}{$88 \mathrm{R}$} & $94811-95263$ & Evrl-air-augmenter of liver regeneration \\
\hline & 149aa & \\
\hline \multirow[t]{2}{*}{$89 R$} & $95331-96497$ & SP \\
\hline & 388aa & \\
\hline \multirow[t]{2}{*}{$90 \mathrm{R}$} & $96590-97981$ & Major capsid protein \\
\hline & 462aa & \\
\hline \multirow[t]{2}{*}{$91 R$} & $98105-99292$ & Immediate-early protein ICP-46 \\
\hline & 394aа & \\
\hline \multirow[t]{2}{*}{$92 \mathrm{R}$} & $99627-99872$ & SP \\
\hline & 80aa & \\
\hline \multirow[t]{2}{*}{$93 \mathrm{~L}$} & $100054-100221$ & SP \\
\hline & $54 a a$ & \\
\hline \multirow[t]{2}{*}{$94 \mathrm{~L}$} & $100331-100798$ & Regina ranavirus P8.141 C-like protein, TM \\
\hline & 154aa & \\
\hline \multirow[t]{2}{*}{$95 R$} & $100891-101982$ & DNA repair protein RAD2, Xeroderma \\
\hline & 362aа & $\begin{array}{l}\text { Pigmentosum G N-region, Helıx-hairpın-helıx, } \\
\text { Class } 2 \text { (Pol I) family }\end{array}$ \\
\hline \multirow[t]{2}{*}{$96 R$} & $102784-103455$ & Unknown protein, SP \\
\hline & 222aа & \\
\hline \multirow[t]{2}{*}{$97 \mathrm{R}$} & 103538-103951 & Myeloid cell leukemia protein, MCL-1, TM \\
\hline & 136аa & \\
\hline \multirow[t]{2}{*}{$98 \mathrm{R}$} & $104649-104849$ & SP \\
\hline & 65aа & \\
\hline
\end{tabular}

*Note: SP-surface protein, TM-transmembrane domain

'Loss of original, predicted start codon in SSME; new start codon 27 bp downstream.

§Loss of original, predicted stop codon in SSME; new stop codon 319 bp upstream.

१39 bp deletion in original 50L ORF of SSME. Loss of ORF 50L's original predicted stop codon in SSME; ORFs $49 \mathrm{~L}$ and $50 \mathrm{~L}$ are now combined as 49/50L.

\#Deletion of 65L ORF and majority of 66L ORFs in SSME.

**18 bp deletion in 87L ORF of SSME.

in 50L when compared to wt-FV3, present only in the SSME genome (Figure 3). In addition, 50L had a single nucleotide deletion resulting in a frameshift mutation in SSME, RGV, and SSTIV when compared to wt-FV3. This frameshift mutation resulted in the loss of 50L's stop codon, which led to the combination of 49L and $50 \mathrm{~L}$ into a single ORF. These two ORFs merged in frame, creating 49/50L. In contrast, TFV did not have this single nucleotide deletion, nor did it display the merger of its 49L and 50L equivalent ORFs (Figure 3). This is consistent with TFV being the most divergent virus of the group.
Table 2 Genetic variation present within the SSME genome as compared to the wt-FV3 reference genome

\begin{tabular}{|c|c|c|}
\hline Region & Change & Affect \\
\hline \multirow[t]{2}{*}{$21,933-24,515 \mathrm{bp}$} & 24 bp substitutions & \multirow{2}{*}{$\begin{array}{l}\text { 24aa substitutions \& 9aa } \\
\text { insertion in } 19 R\end{array}$} \\
\hline & 27 bp insertion & \\
\hline $30,851 \mathrm{bp}$ & 1 bp substitution & $\begin{array}{l}\text { Loss of a start codon in } 24 \mathrm{R} \text {; } \\
\text { new start codon is } 27 \mathrm{bp} \\
\text { downstream, thus } \\
\text { shortening ORF by } 9 \text { aa }\end{array}$ \\
\hline 51,102 bp & 1 bp deletion & Frameshift mutation in 43R \\
\hline 52,769 bp & 1 bp deletion & $\begin{array}{l}\text { Frameshift mutation and loss of } \\
\text { original stop codon in } 46 \mathrm{~L} ; \\
\text { new stop codon is } 319 \mathrm{bp} \\
\text { upstream, thus lengthening } 46 \mathrm{~L}\end{array}$ \\
\hline $54,805 \mathrm{bp}$ & $1 \mathrm{bp}$ deletion & $\begin{array}{l}\text { Loss of original stop codon in } \\
50 \mathrm{~L} \text {, leading to the combination } \\
\text { of ORFs } 49 \mathrm{~L} \text { and } 50 \mathrm{~L}\end{array}$ \\
\hline $54,938 \mathrm{bp}$ & 39 bp deletion & 13aa deletion in $49 / 50 \mathrm{~L}$ \\
\hline $76,105 \mathrm{bp}$ & 757 bp deletion & $\begin{array}{l}\text { Deletion of all of } 65 \mathrm{~L} \text { and the } \\
\text { majority of } 66 \mathrm{~L}\end{array}$ \\
\hline 94,712 bp & 18 bp deletion & 6 aa deletion in 87L \\
\hline $10,4050 \mathrm{bp}$ & 67 bp deletion & $\begin{array}{l}67 \text { bp deletion in non-coding } \\
\text { region between } 97 \mathrm{R} \text { and } 98 \mathrm{R}\end{array}$ \\
\hline
\end{tabular}

Genome region involved, nucleotide change, and end affect of the variation is presented.

Further ranaviral gene variation was discovered in 43R in the form of a single nucleotide deletion, resulting in a frameshift mutation. Similar deletions were found in SSME, RGV, SSTIV, and TFV, leading to pronounced differences in amino acid sequences when compared to wt-FV3 (Figure 4). It is worth noting that although SSME, RGV, and SSTIV share the same frameshift mutation the genes are not identical as there are several single amino acid changes that lead to modest variation (Figure 4). In contrast, despite having a similar nucleotide deletion, TFV's proposed amino acid sequence was markedly different from other analyzed ranaviruses. Another single nucleotide deletion was found in $46 \mathrm{~L}$ (Tables 1 and 2), which led to the loss of the original stop codon and the extension of the ORF by 319 bps (Tables 1 and 2). This was found in all genomes other than TFV and wt-FV3. These data demonstrate that even between very similar viral genomes, there is considerable gene variation, and that when viruses differ in pathogenicity, it could be related to variation in coding regions.

\section{Repeat regions can vary in copy number between viral isolates}

Genomic sequencing, and subsequent analysis, of SSME in comparison to wt-FV3, provided a general overview of the genetic variation between closely related FV3 isolates, particularly in coding regions. We then decided to explore possible genetic variation in highly variable 


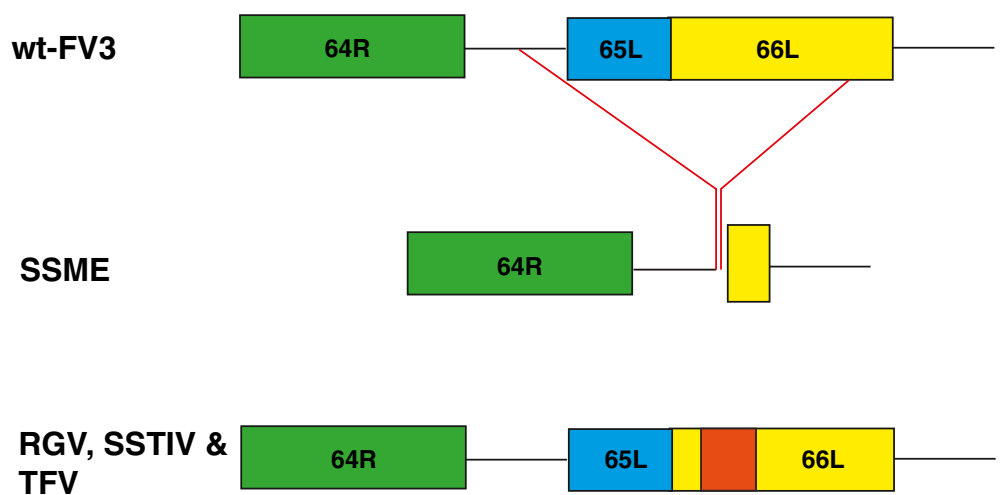

Figure 2 65L \& $66 \mathrm{~L}$ deletion in SSME. Alignment of the 64R-66 region across ranaviruses. A 757 bp deletion is present in the SSME genome, spanning from 76,113-76,869 bp in wt-FV3, deleting all of 65L and most of 66L. A 139 bp insertion is also present in the 66L homologous regions of RGV, SSTIV, and TFV genomes.

repeat regions, and thus define these genetic regions with greater inter-strain variability. To achieve this, we chose three repeat regions (suspected to be polymorphic in copy number) to investigate. These regions included: Region 1 (22,499-22,574 bps); Region 2 (52,443-52,747 bps); and Region 3 (54,948-54,986 bps), based on the wt-FV3 sequence. We performed a repeat analysis on our sequenced SSME genome that we had previously evaluated for coding region variability, and reference genomes RGV, SSTIV, and TFV. We also decided to analyze the repeat regions of wt-FV3 and aza- $\mathrm{C}^{\mathrm{r}}$ in order to check for repeat number stability between the two strains over the multiple viral passages they have undergone since the creation of aza- $\mathrm{C}^{\mathrm{r}}$ in 1987 [22]. In addition, we expanded our analysis to include 6 environmental samples isolated from the same waterway in Manitoulin, Kagawong, ON, Canada. These

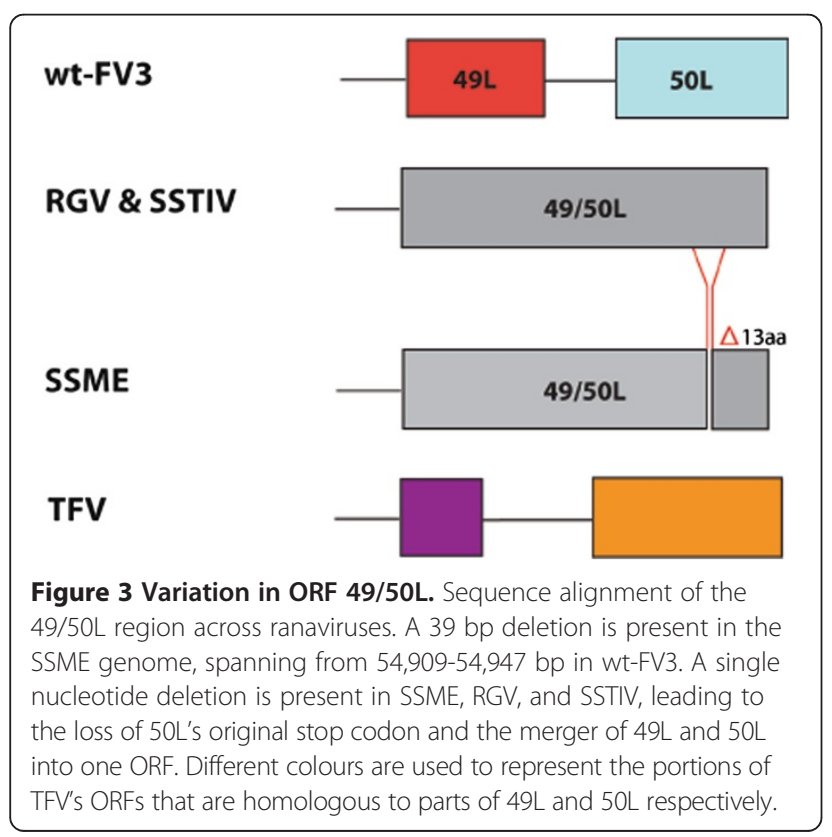

isolates were designated as: $\mathrm{E} 3, \mathrm{E} 4, \mathrm{E} 5, \mathrm{~F} 4, \mathrm{~F} 6$, and $\mathrm{G} 4$; a lab FV3 sample (ATCC ${ }^{\ominus}$ VR-567 ${ }^{\text {mat }}$ ) was also used [26].

The information acquired through analyzing these repeat regions indicated that variation in repeat copy number is present between ranaviral isolates, including those from one geographic location (Figure 5). In the first region, repeat copy number ranged from $2-5$ copies, with 2 copies being the most common and 5 copies being unique to isolate F6. Wt-FV3 and aza- $\mathrm{C}^{\mathrm{r}}$ shared a distinctive repeat sequence, containing a $\mathrm{G}$ rather than an $A$ at the $9^{\text {th }}$ nucleotide position (Figure 5). Region 2 proved to be more variable than region one, with repeat copy number ranging from 4-18 copies, while Region 3 was found to consist of two repeat sequences. These Region 3 repeats varied in copy number between isolates, with a maximum copy number of 4 . However, in some instances, the first sequence of nucleotides characteristic of this region did not repeat (Figure 5).

Although copy number variation was present amongst isolates, when samples were compared across all three repeat regions, some were found to be identical; such isolates included F4, E5, and E3 (Figure 5), which were isolated from the same geographic region. In addition, isolates wt-FV3 and aza- $\mathrm{C}^{\mathrm{r}}$ were also found to be identical across repeat regions (Figure 5), which is consistent with their common origin [22]. This data taken as a whole suggests that viral isolates, even those from one geographic location, can display both variation and identical patterns across repetitive regions of the genome. Thus, these repeats could act as a fingerprint to discriminate between viral isolates.

\section{Discussion}

Our analysis of related ranaviruses presents a novel approach to genomic comparison that differs from other studies. We analyzed the genomes of closely related isolates of FV3 through 454 GS-FLX technology and STR 


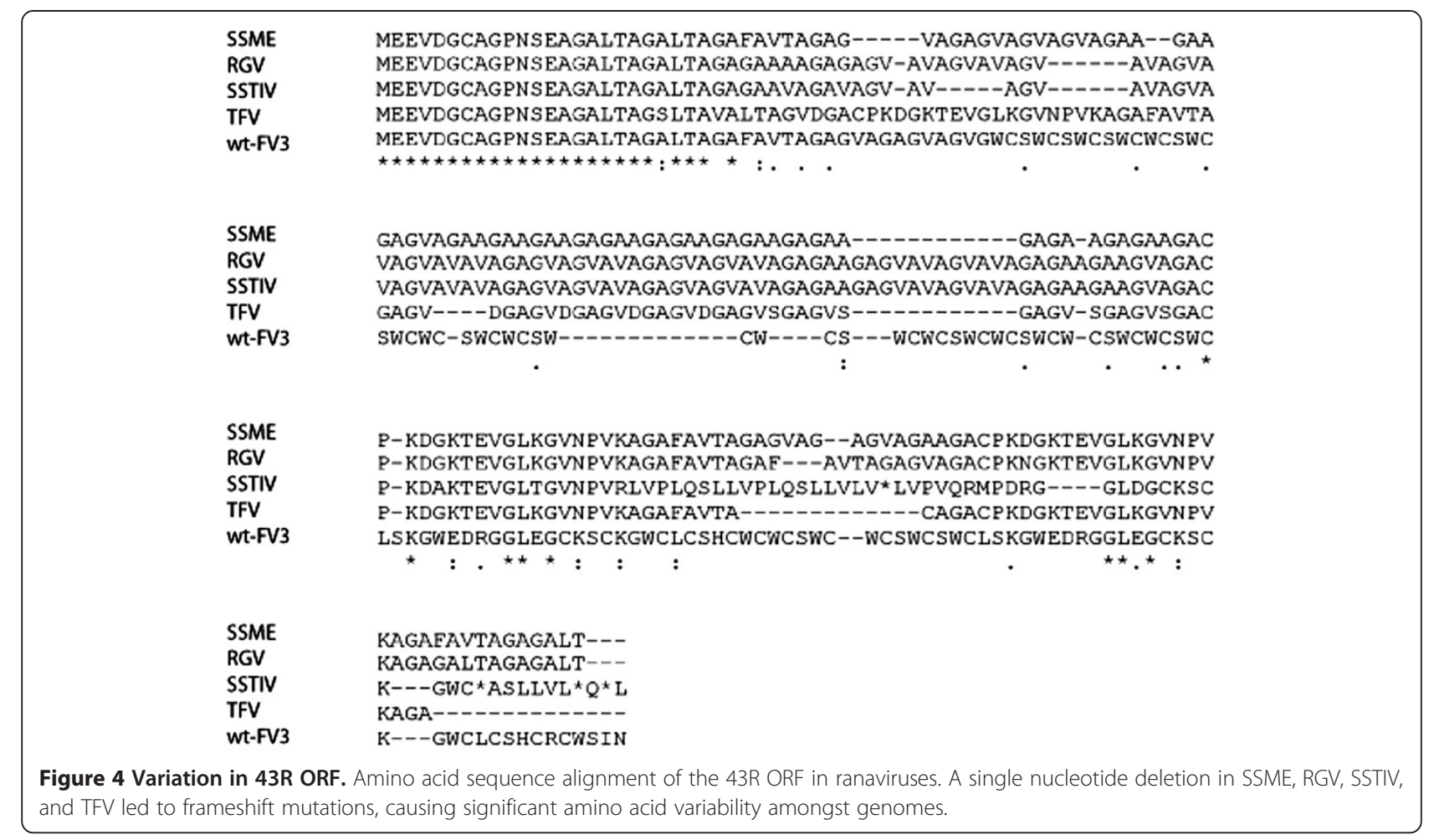

comparison. The scale (fully sequenced genomes), and the nature of comparison (using viral isolates of FV3), set our investigation apart from past studies. We found that the 3 strains we examined displayed slightly different levels of virulence during in vivo studies. By sequencing the one genome yet to be sequenced, we were able to highlight areas that may be important in generating infectious phenotypes of FV3. This kind of analysis has never been done for FV3 or related ranaviruses: thus, it provides greater insight into the genetic variation among these closely related DNA viruses and the possible genetic basis of ranaviral virulence.

Our results demonstrate that genetic variation is present between closely related FV3 isolates in both coding and non-coding regions. The SSME genome was sequenced and compared to the published wt-FV3 genome, along with related ranaviral genomes RGV, SSTIV, and TFV. Comparisons revealed that SSME was divergent from wtFV3, and aza- $C^{\mathrm{r}}$. This variation could be due to the fact that SSME was isolated from a spotted salamander rather

\begin{tabular}{|c|c|c|c|}
\hline Viral Isolate & Region 1 & Region 2 & Region 3 \\
\hline $\mathrm{F} 4, \mathrm{E} 5$, \& E3 & $\frac{\mathbf{x} 2}{- \text { CTGCGAGAAAGTCTC- }}$ & $\begin{array}{c}\mathbf{x} 17 \\
\text {-CTTACGCTTCACAGGGGA- }\end{array}$ & $\begin{array}{cc}\mathbf{x} 2 & \mathbf{x} 4 \\
\text {-TCAGGCTGC-TCAGGCTGT- }\end{array}$ \\
\hline E4 & $\begin{array}{c}\mathbf{x} \mathbf{2} \\
\text {-CTGCGAGAAAGTCTC- }\end{array}$ & $\begin{array}{c}\mathbf{x} 15 \\
\text {-CTTACGCTTCACAGGGGA- }\end{array}$ & $\begin{array}{cc}\mathbf{x} 2 & x 4 \\
- \text { TCAGGCTGC-TCAGGCTGT- }\end{array}$ \\
\hline G4 & $\begin{array}{c}\mathbf{x} 4 \\
\text {-CTGCGAGAAAGTCTC- }\end{array}$ & $\begin{array}{c}\mathbf{x} 14 \\
\text {-CTTACGCTTCACAGGGGA- }\end{array}$ & $\begin{array}{cc}x \mathbf{x} & \mathbf{x} 4 \\
- \text { TCAGGCTGC-TCAGGCTGT- }\end{array}$ \\
\hline wt-FV3 and aca-C ${ }^{r}$ & $\begin{array}{c}\mathbf{x 3} \\
\text {-CTGCGAGAAGGTCTC- }\end{array}$ & $\begin{array}{c}\mathbf{x} 16 \\
\text {-CTTACGCTTCACAGGGGA- }\end{array}$ & $\begin{array}{c}\mathbf{x} 2 \\
- \text { TCAGGCTGC-TCAGGCTGT- }\end{array}$ \\
\hline SSME & $\begin{array}{c}\mathbf{x} 3 \\
\text {-CTGCGAGAAAGTCTC- }\end{array}$ & $\begin{array}{c}\mathbf{x} 16 \\
\text {-CTTACGCTTCACAGGGGA- }\end{array}$ & $\begin{array}{c}\mathbf{x} 2 \\
- \text { TCAGGCTGC-TCAGGCTGT- }\end{array}$ \\
\hline F6 & $\frac{\mathbf{x} 5}{\text {-CTGCGAGAAAGTCTC- }}$ & $\frac{\mathbf{x} 18}{\text {-CTTACGCTTCACAGGGGA- }}$ & $\begin{array}{cc}\mathbf{x} 2 & \mathbf{x} 2 \\
- \text { TCAGGCTGC-TCAGGCTGT- }\end{array}$ \\
\hline VR-567 & $\begin{array}{c}\mathbf{x} \mathbf{4} \\
- \text { CTGCGAGAAGTCTC- }\end{array}$ & $\begin{array}{c}\mathbf{x} 4 \\
- \text { CTTACGCTTCACAGGGGA- }\end{array}$ & $\begin{array}{cc}\mathbf{x} \mathbf{2} & \mathbf{x} \mathbf{2} \\
- \text { TCAGGCTGC-TCAGGCTGT- }\end{array}$ \\
\hline RGV & $\begin{array}{c}\mathbf{x} 2 \\
\text {-CTGCGAGAAAGTCTC- }\end{array}$ & $\begin{array}{c}\mathbf{x} 10 \\
\text {-CTTACGCTTCACAGGGGA- }\end{array}$ & -TCAGGCTGC-TCAGGCTGT- \\
\hline SSTIV & $\begin{array}{c}\mathbf{x 2} \\
\text {-CTGCGAGAAAGTCTC- }\end{array}$ & $\frac{\mathbf{x} 18}{- \text {-CTTACGCTTCACAGGGGA- }}$ & -TCAGGCTGC-TCAGGCTGT- \\
\hline TFV & $\begin{array}{c}\mathbf{x 3} \\
\text {-CTGCGAGAAAGTCTC- }\end{array}$ & -TGAAACAGACTTGCTGTCTC & -TCAGGCT-CCACAACAGCCT- \\
\hline
\end{tabular}

Figure 5 STR variation summary. Short tandem repeats (STRS) vary between viral isolates at three tested locations. Results reveal three isolates (F4, E5, and E3), and two isolates (wt-FV3 and aza-C'), that have the same STR copy number at each location. Areas highlighted in blue are full repeats, with their coinciding copy number above. Areas highlighted in green represent a sequence that may/may not repeat but is very similar to the STR that follows it in the genome, and areas highlighted in pink represent nucleotides that differ from the STR found in the majority of ranaviruses analyzed. 
than anurans, and so the strain may have evolved in order for it to better adapt to its novel host, as is seen during serial passage [27]. For example, the pathogenicity of Dengue virus was altered by serial passaging Dengue virus 27 times which resulted in 25 nucleotide changes between 2 strains [27]. This finding is interesting given the fact that our results also showed that SSME was the least virulent of our 3 strains during an in vivo study in anurans (Figure 1). Thus, genetic mutations observed in SSME, such as deletions in ORFs 65L, 66L and 49/50L, could have had an effect on strain virulence in anuran hosts. Also, past sequencing results [12] as well as our own genomic sequencing of wt-FV3 and aza- $\mathrm{C}^{\mathrm{r}}$ genomes revealed only 13 nucleotide differences (data not shown) between the strains, supporting our in vivo finding that the two strains cause essentially the same amount of tadpole mortality (97\% and $96 \%$ respectively).

One of the most significant genetic variations found in SSME was a 757 bp deletion that deleted all of the $65 \mathrm{~L}$ coding region and most of the $66 \mathrm{~L}$ coding region (Figure 2). Among other ranaviruses, the functions of these genes have not been determined. Further sequencing of ranaviruses has shown that $65 \mathrm{~L}$ is present in both RGV and SSTIV as 69L and 68L respectively $[23,28]$, while this form of $66 \mathrm{~L}$ appears to be unique to FV3, as other ranaviruses have a 139 nucleotide insertion in their related 66L regions (Figure 2). Another genetic variation specific to SSME was a 13 amino acid deletion in ORF 50L (Figure 3). Interestingly, a second variation was found in this area in the form of single nucleotide deletion. This deletion lead to the merger of ORFs 49L and 50L in all examined ranaviruses other than TFV and wt-FV3 (Figure 3). In terms of function, 49L has multiple SAP motifs, which are DNA/RNA binding domains predicted to be involved in chromosomal organization and DNA replication [29]. Thus, this new 49/50L ORF may function in viral replication.

Single nucleotide deletions were found in multiple ranaviruses within the 43R genes (Figure 4) and 46L (Tables 1 and 2 ) genes. In $43 R$, the deletion was present in all ranaviruses analyzed other than wt-FV3, and resulted in a frameshift mutation (Figure 4). In 46L, the original stop codon was lost, leading to the extension of the ORF by 319 bps (Tables 1 and 2). This was found in all genomes other than TFV and wt-FV3. Supposedly, 46L encodes for a neurofilament triplet H1-like protein [12]. However, the extended version of $46 \mathrm{~L}$ that we discovered has a putative conserved domain known as a microneme/rhoptry antigen in the area previously thought to be non-coding. Micronemes and rhoptries are organelles possessed by Apicomplexa protozoans that secrete proteins involved in parasite entry into a host cell, specifically possessing protein-binding motifs that recognize ligands on the host cell surface [30]. Although usually associated with protozoan parasites, these microneme/rhoptry antigens found in 46L could give further indication as to 46L's function.

The changes present in 43R, 46L, 49/50L, 65L, and $66 \mathrm{~L}$ represent the main variable regions amongst the related ranaviral isolates we analyzed. This suggests that these are changeable areas across ranaviruses, and could be used in the future to help explain variable infectious phenotype. Moreover, multiple amino acid deletions present in $65 \mathrm{~L}, 66 \mathrm{~L}$, and $49 / 50 \mathrm{~L}$, were limited to the SSME strain, which displayed the lowest level of virulence during tadpole infection. Thus, changes that are unique to SSME may present areas of the genome that are particularly effective in viral attenuation, specifically in an alternative host. As FV3 mortality and morbidity continues to worsen and fluctuate across environmental regions, examination of these genomic areas may prove useful as an initial way to investigate the genetic basis behind infective changes [6]. Further research could be used to explain variations in the virulence of different FV3-like isolates.

As we had already identified variation in the coding regions of closely related FV3 isolates, we decided to further our understanding of variation within highly variable sites by investigating 3 recently identified STR regions [19]. These are known to be variable areas: for instance, although FV3 and SSTIV share 99\% genome sequence identity, they share only approximately $50 \%$ of repeats in common [19]. Thus, we predicted that these repeat regions would have greater inter-strain variability that would provide useful information when trying to understand overall genetic variability between ranaviral isolates. In order to test this prediction, we analyzed our sequenced SSME genome and reference ranaviral genomes, along with 6 environmental samples isolated from the same waterway. We also sequenced wt-FV3 and aza- $\mathrm{C}^{\mathrm{r}}$ to check for repeat number stability across their past viral passages. Analysis revealed that repeat copy number was variable between isolates, even between those from the same geographic location, but that there was some conservation (Figure 5). Specifically, wt-FV3 and aza-C $C^{\mathrm{r}}$ were identical, and samples F4, E5, and E3 were also identical at all three regions (Figure 5); this finding was not surprising given that aza-C $\mathrm{C}^{\mathrm{r}}$ is the result of the wt-FV3 strain treated with azacytidine and does not necessarily represent a strain with a separate evolutionary history [22]. It also implies stability in the repeat regions, as these regions have not changed between the two strains since their initial separation. However, the finding that viral isolates from the same geographical area have variability may limit the use of STRs as a geographic marker. This STR analysis allowed us to better quantify the small scale genetic variation that is present in highly variable genetic sites amongst FV3 isolates, thus 
furthering our understanding of genetic variation beyond coding regions.

The STR analysis we performed in our study has the potential to contribute to our understanding of FV3 tracking and strain designation. Surveillance and phylogeographical analysis of FV3 are pivotal in understanding how the pathogen varies between different habitat sites and amphibian species, as well as for revealing possible sources of a disease outbreak [31]. It can also have direct effects on conservation by aiding in strategy development to minimize die-offs in high-risk areas, and in creating vaccines through knowledge of the FV3 genome itself $[14,31]$. However, exact taxonomic identification of viruses in amphibian populations has been difficult given the lack of detailed molecular data on FV3 and other ranaviruses. The methodology used to classify these viruses in the past has been through comparing the major capsid protein (MCP) of different viral isolates [3]. However, the use of the MCP as a tool to distinguish between different ranaviruses, as well as between different strains of the same virus, has been called under scrutiny $[24,32,33]$. Thus, there is a need to develop new methods of strain tracking for ranaviral isolates.

The use of STRs for ranavirus strain identification has precedence in other virus studies. In one such study, 12 isolates of human cytomegalovirus (HCMV) were isolated from various individuals infected with the virus. The isolates were then tested for variable repeats in 24 polymorphic regions, and based on this analysis, each viral isolate was designated as an individual strain of HCMV [34]. Many of the HCMV repeats used in this study were found in non-coding regions of the genome, similarly to the ones used in our study. The study suggested that these changes in repeats are evolutionarily neutral and so appropriate for strain identification, not only in HCMV, but in other similar, large genome DNA viruses [34].

Other studies have used coding instead of non-coding repeat regions to identify viral strains $[35,36]$. In our study, Region 1 is found in the 19R ORF, unlike the non-coding areas of Regions 2 and 3. There are many examples of functional microsatellites that are known to affect viral characteristics based on copy number, including hepatitis $C$ virus and vesicular stomatitis virus $[35,36]$. Therefore, in addition to being potentially useful in viral tracking, STRs from the Region 1 coding region may have functional significance in FV3.

\section{Conclusions}

In this study we have been able to uncover fine scale genetic variation between closely related ranaviral isolates that have different levels of virulence. We have shown that substantial genetic variability is present between closely related FV3 isolates, both in terms of deletions/insertions, and even more so at select STR locations. These genomic areas with deletions/insertions may present regions that affect viral infectious phenotype, and therefore require investigation. Furthermore, we have identified STR regions that may prove useful in future phylogeographical tracking and identification of ranaviral strains across different environmental regions. As FV3 leads to more unexplained lethal infections in amphibian populations, studies such as this are necessary. The genetic insight that they provide into ranaviral genomes will prove invaluable when seeking to explain the variability of FV3 infectious phenotype in wild populations, and in preventing the devastation that ensues.

\section{Material and methods \\ Reagents, viruses}

FV3 isolate SSME, wt-FV3, and aza- $\mathrm{C}^{\mathrm{r}}$, were analyzed in this study and were provided by Professor Gregory Chinchar from the University of Mississipi Medical Center (Jackson, MS, USA). SSME was isolated from a wild, spotted salamander population in Maine, USA, while aza- $\mathrm{C}^{\mathrm{r}}$ was derived from the laboratory wt-FV3 strain through selection with azacytidine [22]. Both wt-FV3 and aza- $\mathrm{C}^{\mathrm{r}}$ have been previously sequenced and found to be identical, with wt-FV3's nucleotide sequence deposited into GenBank [12]. Amphibian renal cells (A6 cells) were supplied by Niels Bols of the University of Waterloo and maintained in Leibovitz's L-15 media (Invitrogen, Burlington, ON) supplemented with $10 \%$ fetal bovine serum (FBS; Invitrogen, Burlington, ON), penicillin $(100 \mathrm{U} / \mathrm{ml})$, and streptomycin $(100 \mu \mathrm{g} / \mathrm{ml})$.

\section{Infection of tadpoles with FV3}

In order to monitor survival of FV3 infected tadpoles, we obtained Lithiobates pipiens tadpoles, approximately Gosner stage 25 [37], from the Environment Canada Atlantic Laboratory for Environmental Testing in Moncton, NB., courtesy of Paula Jackman. The animals were received two weeks prior the beginning of the experiment and were kept in $20 \mathrm{~L}$ tanks filled with $10 \mathrm{~L}$ of aged clean dechlorinated water. Each treatment group was done as 2 replicates of 25 tadpoles per treatment. Groups tadpoles were placed in dechlorinated water, with the host density (number of tadpoles per volume of water) adjusted to 1 tadpole per $250 \mathrm{~mL}$ to avoid any effect of density on tadpole development [38]. To infect, 25 tadpoles were placed in $50 \mathrm{~mL}$ of infected water containing $10,000 \mathrm{pfu} / \mathrm{mL}$ of a FV3 strain (SSME, wt-FV3, and aza-C ${ }^{\mathrm{r}}$ ). According to past experiments, such concentration is known to induce sublethal effects in these laboratory conditions [38]. Control individuals were placed within $50 \mathrm{ml}$ of FV3-free water. The tadpoles were left within the infected solution overnight (12 hours) tadpoles were then transferred together with the contaminated water in $2 \mathrm{~L}$ 
plastic containers filled with $1 \mathrm{~L}$ of dechlorinated water (aged for three days) for the rest of the experiment. Containers were held in a climatic chamber (Thermo Incubator Model 3740) where the temperature was set to remain at $22^{\circ} \mathrm{C}$ with a $12 \mathrm{~h}: 12 \mathrm{~h}$ dark:light cycle. Tadpoles were fed on a weekly basis after the water was changed with standard tadpole food (Carolina Biological Supply Company, Burlington, NC) at $30 \mathrm{mg} /$ tadpole for week 1, $60 \mathrm{mg} /$ tadpole for week 2 , and $120 \mathrm{mg} /$ tadpole for week 3 until the end of the experiment [38]. Starting on week 3 the water in each tank was replaced once a week with clean dechlorinated aged ( $24 \mathrm{~h}$ ) water. As a result, exposed tadpoles were held in virus-containing water for 3 weeks, a period which is long enough for tadpoles to be in close proximity with residual infection [38]. Tanks were monitored on a daily basis. Dead tadpoles were removed to prevent any scavenging, and stored at $-25^{\circ} \mathrm{C}$ in individual plastic vials with ethanol for subsequent analyses.. The experiment terminated when all the individuals died or reached metamorphosis. The procedures used in this experiment follow protocol \#2010-04-02 approved by the Laurentian University Animal Care Committee.

\section{Screening of tadpoles for FV3}

In order to check for ranavirus infection, all animals (including euthanized ones) were dissected to remove the liver that was then crushed into a $1.5 \mathrm{ml}$ Eppendorf tube. The resulting tissue mixture was used for DNA extraction. DNA was extracted using QIAmp DNeasy Kit following the standard protocol (Qiagen). After extraction, a double blind PCR was performed using a primer set known to successfully amplify a portion of the major capsid protein within the FV3 genome: MCP-ranavirus-F (5'-GACTTGGCCACTTATGAC-3') and MCP-ranavirus-R (5' - GTCTCTGGAGAAGAAGAA), following the PCR conditions listed in Mao et al. [33], using $1.5 \mu \mathrm{l}$ of template DNA and cycled 40 times. Individuals showing two positive amplifications for both PCRs were considered infected. We analyzed host survival using a survival analysis and failure time analysis following the Kaplan \& Meier product limit method associated with Chi square and Gehan's Wilcoxon tests (multiple and two sample comparisons respectively) [39]. Individuals surviving to the end of the experiment were censored to account for our lack of information about their true time of death [40].

\section{Viral DNA isolation}

The SSME viral isolate was propagated on a confluent monolayer of A6 cells, and grown in a $75 \mathrm{~cm}^{2}$ flask, with cells infected at a multiplicity of infection (MOI) of $1 \mathrm{PFU} / \mathrm{cell}$. The cells were harvested 5 days post infection (once cytopathic effect appeared), and viral DNA was extracted using the Purelink Viral RNA/DNA
Mini Kit according to manufacturer's protocol (Invitrogen, Burlington, $\mathrm{ON}$ ).

\section{Viral genome sequencing}

Standard kits and protocols developed by the manufacturer were used to sequence the SSME sample on a 454 GS-FLX platform (Roche Diagnostics Corporation). Briefly, a Rapid Library Preparation Kit (Roche, Mississauga, ON) was used to mechanically shear $500 \mathrm{ng}$ of template DNA into short fragments. A universal sequencing primer that included a short DNA sequence unique to the sample (MID tag) was then annealed to both ends of each DNA fragment. A GS Junior Titanium Emulsion PCR Kit (Roche, Mississauga, ON) was used to amplify the sample library, which was sequenced using a GS Junior Titanium Sequencing Kit (Roche, Mississauga, ON). In order to assemble a full genomic sequence, the short sequences produced by 454 sequencing were aligned with the reference FV3 genome, wt-FV3, using GS Reference Mapper (Roche, Mississauga, ON). Any gaps in the assembled genome were then sequenced using custom PCR primers specific to each gap, with sequencing performed by the Robarts Sequencing Facility (London, ON). The final genomic sequence was deposited in GenBank accession number KJ175144.

\section{FV3 sample collection}

FV3 environmental samples were collected from frogs caught by hand at various sites along a lakeshore in Manitoulin, Kagawong, ON, Canada (Latitude: 45.86418, Longitude: -82.27150 ). The frogs were caught using disposable gloves which were changed between each animal inspection. This method is preferred to the "net-catching method' as it has been suggested that cross contamination can occur via the net. Each individual was toe clipped following the protocol \#2009-03-04 approved by the Laurentian University Animal Care Committee for tissue sample collection. DNA was then isolated from toe clippings using the DNeasy Blood \& Tissue Kit according to the manufacturer's protocol for total DNA extraction from animal tissues (Qiagen, Mississauga, ON). Samples then underwent PCR with primers designed to amplify specific repeat regions identified in Eaton et al. [19]. Primers used included: Region 1-F: CGTGGTCAGACT GGTCCTCG; Region 1-R: CACCTCTGTCTCTGAATC GG; Region 2-F: GAGTTTACTTGGTGGCCATG; Region 2-R: TCCTGTCAAGAGATCCCCTC; Region 3-F: CTTG CTGCTGCCGTTCAGGC; and Region 3-R: AGAGTGA AAAAGGTAAAGGC.

\section{Sequencing repeats and confirming 454 sequence reads} In a PCR reaction tube the following reactants were combined: 10X PCR buffer (Invitrogen, Burlington, ON), $50 \mathrm{mM} \mathrm{MgCl}_{2}$ solution (Invitrogen, Burlington, ON), 5X 
TAQ DNA polymerase (Invitrogen, Burlington, ON), $10 \mathrm{mM}$ deoxyribonucleotide triphosphates (dNTPs), $0.1 \mathrm{mM}$ primer, $2.5 \mathrm{ng} \mathrm{DNA}$, and water to a final volume of $50 \mu \mathrm{l}$. The reactions were then placed in a thermocycler under the following conditions: $94^{\circ} \mathrm{C}$ for 3 minutes, $94^{\circ} \mathrm{C}$ for 30 seconds, $56^{\circ} \mathrm{C}$ for 1 minute, and $72^{\circ} \mathrm{C}$ for 1 minute for 30 cycles. Sequences of PCR products were determined by Robarts Research Institute DNA Sequencing Facility in London, ON, and were analyzed using BioEdit v7.0.5.

\section{Competing interests}

The authors declare that they have no competing interests.

\section{Authors' contributions}

EAM participated in the design of the study, isolated viral strains in vitro, carried out the molecular genetic studies, participated in 454 GS-FLX sequence alignment, and drafted the manuscript. SG participated in 454 GS-FLX sequence alignment. PE collected viral isolates from the field, carried out the immunoassays, and participated in the design of the study. DL participated in the design of the immunoassays. CJK oversaw the 454 GS-FLX sequencing. CRB conceived of the study, and participated in its design and coordination and helped to draft the manuscript. All authors have read and approved the final manuscript.

\section{Acknowledgements}

This work was supported by Discovery Grants (Natural Science and Engineering Research Council (NSERC) of Canada) to CRB, CJK, and DL. EAM is the recipient of a NSERC postgraduate scholarship and past recipient of a NSERC Undergraduate Research Award.

\section{Author details}

'Department of Biology, Trent University, 1600 East Bank Dr., Peterborough, Ontario K9J 7B8, Canada. ${ }^{2}$ Current address: Department of Biology, Western University, 1151 Richmond Street, London, Ontario N6A 5B7, Canada. ${ }^{3}$ Genetics and Ecology of Amphibians Research Group (GEARG), Department of Biology, Laurentian University, Sudbury, Ontario P3E 2C6, Canada.

Received: 22 October 2013 Accepted: 6 March 2014

Published: 12 March 2014

\section{References}

1. Berger $L$, Speare R, Daszak P, Green DE, Cunningham AA, Goggin $C L$, Slocombe R, Ragan MA, Hyatt AD, McDonald KR, Hines HB, Lips KR, Marantelli G, Parkes H: Chytridiomycosis causes amphibian mortality associated with population declines in the rain forests of Australia and Central America. Proc Natl Acad Sci U S A 1998, 95:9031-9036.

2. Daszak P, Berger L, Cunninham AA, Hyatt AD, Green DE, Speare R: Emerging infectious diseases and amphibian population declines. Emerg Infect Dis 1999, 5:735-748.

3. Tidona CA, Schnitzler P, Kehm R, Darai G: Is the major capsid protein of iridoviruses a suitable target for the study of viral evolution? Virus Genes 1998, 16:59-66.

4. King A, Adams M, Carstens E, Lefkowitz E: Family Iridoviridae, In: Virus Taxonomy: Ninth Report of the International Committee on Taxonomy of Viruses. San Diego: Academic Press; 2012. pp 193-207.

5. Daszak $\mathrm{P}$, Cunningham A, Hyatt $\mathrm{H}$ : Infectious disease and amphibian population declines. Divers Distrib 2003, 9:141-150.

6. Lesbarrères D, Balseiro A, Brunner J, Chinchar VG, Duffus A, Kerby J, Miller DL, Robert J, Schock DM, Waltzek T, Gray MJ: Ranavirus: past present and future. Biol Lett 2012, 8:481-483.

7. Marsh IB, Whittington RJ, O'Rourke B, Hyatt AD, Chisholm O: Rapid differentiation of Australian, European and American ranaviruses based on variation in major capsid protein gene sequence. Mol Cell Probes 2002, 16:137-151.

8. Stuart SN, Chanson JS, Cox NA, Young BE, Rodrigues AS, Fischman DL, Waller RW: Status and trends of amphibian declines and extinctions worldwide. Science 2004, 306:1783-1786.
9. Muths E, Gallant AL, Campbell Grant EH, Battaglin WA, Green DE, Staiger JS, Walls SC, Gunzburger MS, Kearney RF: The amphibian research and monitoring initiative (ARMI): 5-year report. US Geological Survey. Sci Invest Rep 2006, 5224:77.

10. Green DE, Converse KA, Schrader AK: Epizootiology of 64 amphibian morbidity and mortality events in the USA, 1996-2001. Ann N Y Acad Sci 2002, 969:323-339.

11. Chinchar $V$, Ranavirus (family Iridoviridae): Emerging cold-blooded killers. Arch Virol 2002, 147:447-470.

12. Tan W, Barkman T, Chinchar V, Essani K: Comparative genomic analyses of frog virus 3, type species of the genus Ranavirus (family Iridoviridae). Virology 2004, 323:70-84

13. Chinchar VG, Bryan L, Wang J, Long S, Chinchar GD: Introduction of apoptosis in frog virus 3-infected cells. Virology 2003, 306:303-312.

14. Williams T, Barbosa-Solomieu V, Chinchar GD: A decade of advances in iridovirus research. In Advances in virus research, Volume 65. Edited by Maramorosch K, Shatkin A. New York: Academic Press; 2005:173-248.

15. Cunningham AA, Langton TE, Bennett PM, Lewin JF, Drury SE, Gough RE, Macgregor SK: Pathological and microbiological findings from incidents of unusual mortality of the common frog (Rana temporaria). Philos Trans R Soc Lond B 1996, 351:1539-1557.

16. Kidd-Ljunggren $K$, Miyakawa $Y$, Kidd A: Genetic variability in hepatitis B viruses. J Gen Virol 2002, 83:1267-1280.

17. Stuyver L, De Gendt S, Van Geyt C, Zoulim F, Fried M, Schinazi RF, Rossau R: A new genotype of hepatitis $B$ virus: complete genome and phyogenetic relatedness. J Gen Virol 2000, 81:67-74.

18. Wang J, Hoper D, Beer M, Osterrieder N: Complete genome sequence of virulent duck enteritis virus (DEV) strain 2085 and comparison with genome sequences of virulent and attenuated DEV strains. Virus Res 2011, 160:316-325.

19. Eaton HE, Ring BA, Brunetti CR: The genomic diversity and phylogenetic relationship in the family Iridoviridae. Viruses 2010, 2:1458-1475.

20. Kass D, Batzer M: Genome organization/human. Life Sciences: Encyclopedia of 2001:1-8.

21. Chinchar $V$, Granoff A: Temperature-sensitive mutants of frog virus 3 : biochemical and genetic characterization. J Virol 1986, 58:192-202.

22. Essani K, Goorha R, Granoff A: Mutation in a DNA-binding protein reveals an association between DNA-methyltransferase activity and a 26,000-Da polypeptide in frog virus 3-infected cells. Virology 1987, 161:211-217.

23. Lei $X$, Ou T, Zhu R, Zhang Q: Sequencing and analysis of the complete genome of Rana grylio virus (RGV). Arch Virol 2012, 157:1559-1564.

24. Hyatt AD, Gould A, Zupanovic Z, Cunningham AA, Hengstberger S, Whittington RJ, Kattenbelt J, Coupar BE: Comparative studies of piscine and amphibian iridoviruses. Arch Virol 2000, 145:301-331.

25. He J, Lu L, Deng M, He H, Weng S, Wang XH, Zhou SY, Long QX, Wang XZ Chan SM: Sequence analysis of the complete genome of an iridovirus isolated from the tiger frog. Virology 2002, 292:185-197.

26. Granoff A, Came P, Breeze D: Viruses and renal carcinoma of Rana pipiens. Virology 1966, 29:133-148.

27. Puri $\mathrm{B}$, Nelson WM, Henchal EA, Hoke $\mathrm{CH}$, Eckels KH, Dubois DR, Porter KR, Hayes CG: Molecular analysis of dengue virus attenuation after serial passage in primary dog kidney cells. J Gen Virol 1997, 78:2287-2291.

28. Huang Y, Huang X, Liu H, Gong J, Ouyang Z, Cui H, Cao J, Zhao Y, Wang X, Jiang Y, Qin Q: Complete sequence determination of a novel reptile iridovirus isolated from soft-shelled turtle and evolutionary analysis of Iridoviridae. BMC Genomics 2009, 10:224.

29. Boyle K, Arps L, Traktman P: Biochemical and genetic analysis of the vaccinia virus $D 5$ protein. Multimerization-dependent APTase activity is required to support viral DNA replication. J Virol 2007, 81:844-89.

30. Striepen B, Soldati D, Garcia-Reguet N, Dubremetz JF, Roos D: Targeting of soluble proteins to the rhoptries and micronemes in Toxoplasma gondii. Mol Biochem Parasitol 2001, 113:45-53.

31. Jancovich JK, Davidson EW, Parameswaran N, Mao J, Chinchar VG, Collins JP, Jacobs BL, Storfer A: Evidence for emergence of an amphibian iridoviral disease because of human-enhanced spread. Mol Ecol 2005, 14:213-224.

32. Gray MJ, Miller DL, Hoverman JT: Ecology and pathology of amphibian ranaviruses. Dis Aquat Organ 2009, 87:243-266.

33. Mao J, Hedrick RP, Chinchar VG: Molecular characterization, sequence analysis, and taxonomic position of newly isolated fish iridoviruses. Virology 1997, 229:212-220. 
34. Davis $C$, Field D, Metzgar D, Saiz R, Morin P: Numerous length polymorphisms at short tandem repeats in human cytomegalovirus. J Virol 1999, 73:6265-6270.

35. Barr JN, Whelan SPJ, Wertz GW: cis-acting signals involved in termination of vesicular stomatitis mRNA synthesis include the conserved AUAC and the U7 signal for polyadenylation. J Virol 1997, 71:8718-8725.

36. Yamada N, Tanihara K, Takada A, Yorihuzi T, Tsutsumi M, Shimomura H, Tsuji T, Date T: Genetic organization and diversity of the $3^{\prime}$ non-coding region of the hepatitis C virus genome. Virology 1996, 223:255-261.

37. Gosner KL: A simplified table for staging anuran embryos and larvae with notes on identification. Herpetologica 1960, 16:183-190.

38. Echaubard P, Little K, Pauli B, Lesbarrères D: Context-dependent effects of ranaviral infection on Northern Leopard frog life history traits. PLoS One 2010, 5:e13723.

39. Gehan EA: A generalized wilcoxon test for comparing arbitrarily singly-censored samples. Biometrika 1965, 52:203-223.

40. Leung KM, Elashoff RM, Afifi AA: Censoring issues in survival analysis. Annu Rev Public Health 1997, 18:83-104.

doi:10.1186/1743-422X-11-46

Cite this article as: Morrison et al:: Complete genome analysis of a frog virus 3 (FV3) isolate and sequence comparison with isolates of differing levels of virulence. Virology Journal 2014 11:46.

\section{Submit your next manuscript to BioMed Central and take full advantage of:}

- Convenient online submission

- Thorough peer review

- No space constraints or color figure charges

- Immediate publication on acceptance

- Inclusion in PubMed, CAS, Scopus and Google Scholar

- Research which is freely available for redistribution 